TEME, г. XLIV, бр. 4, октобар - децембар 2020, стр. 1499-1512

\begin{tabular}{lr}
\hline \hline Оригинални научни рад & https://doi.org/10.22190/TEME190702088K \\
Примљено: 2. 7. 2019. & UDK 336.71 \\
Ревидирана верзија: 16. 2. 2020. & $336.77: 005.334$ \\
Одобрено за штампу: 1. 12. 2020. &
\end{tabular}

\title{
АКТУАРСКИ МЕТОД ПРОЦЕНЕ ВЕРОВАТНОЪЕ НЕИЗВРШЕЊА ОБАВЕЗА ДУЖНИКА У БАНКАРСКОМ СЕКТОРУ
}

\author{
Јелена Кочовић $^{1 *}$, Жељко Јовић ${ }^{2}$, Марија Копривица ${ }^{1}$ \\ ${ }^{1}$ Универзитет у Београду, Економски факултет, Београд, Република Србија \\ ${ }^{2}$ Народна банка Србије, Београд, Република Србија \\ *jelena.kocovic@ekof.bg.ac.rs
}

\begin{abstract}
Апстракт
У земљама са недовољно развијеним тржиштем капитала и банкоцентричним финансијским системом, вероватноћа неизвршења обавеза дужника у банкама може се израчунати применом актуарског метода. Овај метод заснива се на употреби података из кредитне евиденције банака о случајевима немогућности извршења обавеза дужника. У циљу оцене нивоа кредитног ризика и идентификације његових детерминанти, применом актуарског метода на емпиријске податке о банкарском сектору Републике Србије израчунате су стопе неизвршења обавеза по хомогеним групама привредних друштава као дужника и по хомогеним групама банака. Резултати истраживања показују да постоје разлике у нивоу кредитног ризика у зависности од величине привредног друштва и припадности сектору привредне делатности, као и да су привредна друштва са нижом зарађивачком способношћу, већом задуженошћу и споријим обртом активе склонија дифолту. Истовремено, показано је да ниво кредитног ризика банке варира у зависности од врсте власништва, величине, профитабилности и капитализованости банке, као и одређених карактеристика њеног портфолија. Добијени резултати су основ за анализу кредитног ризика појединих категорија дужника и банака, као и за избор варијабли које ће бити укључене у економетријске моделе за процену нивоа кредитног ризика у банкарском сектору Србије.
\end{abstract}

Кључне речи: вероватноћа неизвршења обавеза дужника, актуарски метод, кредитни ризик, банкарски сектор.

\section{ESTIMATING PROBABILITY OF DEFAULT IN BANKING SECTOR - THE ACTUARIAL METHOD}

\begin{abstract}
In countries with insufficiently developed capital market and a bankocentric financial system, the probability of default of banking clients can be estimated using an actuarial method. This method uses historical data from banking portfolios on the cases of debtors' inability to meet their obligations towards the bank. In order to assess the level of credit
\end{abstract}


risk and to identify its determinants, we calculated default rates by homogeneous groups of business entities as debtors, and by homogeneous groups of banks through the application of the actuarial method on empirical data from the banking sector of the Republic of Serbia. The research results show that there are differences in the level of credit risk, depending on the size of the business entity and its business sector, as well as that the entities with lower earning capacity, higher indebtedness and slower turnover of assets are more inclined to default. At the same time, it is shown that the default rate of bank varies depending on the ownership type, the bank's size, profitability, capitalization and certain characteristics of its portfolio. The obtained results are the basis for analyzing the credit risk of certain categories of debtors and banks and for selecting variables that will be included in econometric models for assessing the level of credit risk in the banking sector in Serbia.

Key words: $\quad$ probability of default, actuarial method, credit risk, banking sector.

\section{УВОД}

Процена вероватноће да дужник неће бити способан да благовремено измирује своје обавезе обично је први корак у мерењу и управљању кредитним ризиком (Hamilton \& Cantor, 2006). Ова процена може бити добијена применом актуарског метода или метода заснованог на тржишним ценама (Jorion, 2011). У земљама са развијеним тржиштем капитала, за израчунавање вероватноће неизвршења обавеза дужника у банкама користи се метод заснован на тржишним ценама. За земље које немају довољно развијено тржиште капитала са кога се могу очитавати информације релевантне за утврђивање вероватноће неизвршења обавеза дужника прикладан је актуарски метод. Предмет рада су теоријско-методолошке основе актуарског метода процене вероватноће неизвршења обавеза дужника и његова примена на емпиријске податке о банкарском сектору Републике Србије.

У анализи процене параметара кредитног ризика у складу са Базел II стандардима, Енглмен и Рахмејер (Engelman \& Rauhmeier, 2006) посебну пажњу посвећују методама за процену вероватноће неизвршења обавеза дужника, укључујући актуарски метод. У циљу развоја скоринг-модела за компаније из портфолија аустријских и немачких банака, израчунавање вероватноће неизвршења обавеза по рејтинг-категоријама спроведено је применом актуарског метода (Hayden, 2002). Међу неколицином квантитативних модела за процену кредитног ризика, посебно се издваја CreditRisk+ (Credit Suisse, 1997), који је заснован управо на актуарском методу. Базелски комитет за супервизију банака указује на значај актуарског метода за израчунавање миграционих матрица у процени кредитног ризика (Basel Committee on Banking Supervision, 1999). Литература обилује истраживањима утицаја макроекономских фактора на ниво кредитног ризика у банкама (Pesola, 2007; Nkusu, 2011; Castro, 2013), док су ређа истра- 
живања која се баве дејством специфичних фактора тог ризика, било у сегменту привреде (Altman \& Sabato, 2007; Belotti \& Crook, 2013), или у банкарском сектору (Podpiera \& Weill, 2008; Almazari, 2014).

Модел кредитног скоринга, који је предложен за предузећа која послују у Републици Србији, заснива се на логистичкој регресији и великом броју показатеља израчунатих на основу финансијских извештаја (Nikolić, Žarkić-Joksimović, Stojanovski, \& Joksimović, 2013). Вредности неких од варијабли у економетријском моделу развијеном за потребе идентификације специфичних фактора кредитног ризика у домаћем банкарском сектору израчунате су коришћењем актуарског метода (Jović, 2017b).

Циљ овог рада је оцена нивоа кредитног ризика и идентификовање његових могућих детерминанти на нивоу клијента и на нивоу банке у банкарском сектору Србије у контексту погоршаних макроекономских услова након наступања глобалне економске кризе 2007/08. године. Применом актуарског метода, у раду су израчунате вероватноће неизвршења обавеза дужника, као и вероватноће да банка уђе у статус дифолта, по одређеним хомогеним групама, формираним на основу посматраних карактеристика њихове ризичности.

\section{ТЕОРИЈСКО-МЕТОДОЛОШКЕ ОСНОВЕ АКТУАРСКОГ МЕТОДА}

Процена вероватноће неизвршења обавеза дужника у банкама применом актуарског метода заснива се на историјским подацима о случајевима дифолта дужника из портфолија банке. Вероватноћа неизвршења обавеза дужника на нивоу целокупног портфолија може бити израчуната као:

$$
P D_{t}=\frac{m(D)_{t}}{m(N D)_{t-1}},
$$

где су:

$P D_{t}$ - вероватноћа неизвршења обавеза дужника у периоду $t$;

$m(D)_{t}$ - број клијената који је током периода $t$ завршио у статусу неизвршења обавеза, тј. у статусу дифолта, уколико дифолт пратимо током одређеног циклуса (енгл. Through The Cycle - TTC), односно број клијената који је на крају периода $t$ у статусу дифолта, уколико дифолт пратимо у некој тачки времена (енгл. Point in Time - PIT);

$m(N D)_{t-1}-$ број клијената који се на почетку периода $t$ налазио ван статуса дифолта.

Образац (1) подразумева да се вероватноћа неизвршења обавеза израчунава само за један период, најчешће годину дана. Ипак, теоријски приступи и стандарди струке захтевају да се обрачуном обухвати већи број година, најмање четири године до пет година, колико траје један пословни циклус. У том случају, једногодишња стопа неизвршења обавеза може се исказати на следећи начин: 


$$
P D=\frac{\sum_{i=1}^{t} m(D)_{i}}{\sum_{i=1}^{t} m(N D)_{i-1}} .
$$

Приказане дефиниције вероватноће неизвршења обавеза подразумевају да се укупан портфолио банке само дели на портфолио у статусу неизвршења обавеза (дифолта) и портфолио ван статуса неизвршења обавеза. У пракси преовладава случај да банке свој портфолио, који се не налази у статусу дифолта, деле по нивоима кредитног квалитета на основу рејтинг-оцена екстерних рејтинг-агенција или интерно развијене рејтинг-скале, а да се вероватноћа неизвршења обавеза рачуна за сваку рејтинг-категорију посебно. За произвољну рејтинг-категорију $j$ можемо израчунати вероватноћу неизвршења обавеза дужника на следећи начин:

$$
P D_{j}=\frac{\sum_{i=1}^{t} m(D)_{i j}}{\sum_{i=1}^{t} m(N D)_{(i-1) j}} .
$$

Посебан методолошки алат за израчунавање вероватноће неизвршења обавеза по рејтинг-категоријама представља миграциона матрица. Миграциона матрица показује миграцију клијената из једне у другу категорију рејтинга и из одређене рејтинг-категорије у статус дифолта током посматраног периода (Јовић, 2017a). Претпостављајући да интерно развијена рејтинг-скала банке има седам рејтингкатегорија за клијенте ван статуса дифолта (Aaa, $A a a, A, B a a, B a, B$ и $C)$ и једну рејтинг-категорију која означава статус дифолта, можемо дати пример једногодишње миграционе матрице у апсолутним вредностима (Табела 1).

Табела 1. Једногодишња миграциона матрица

\begin{tabular}{|c|c|c|c|c|c|c|c|c|c|c|}
\hline \multicolumn{11}{|c|}{ Рејтинг на крају године } \\
\hline \multirow{8}{*}{ 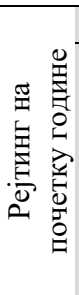 } & & Aaa & $\mathrm{Aa}$ & A & $\mathrm{Baa}$ & $\mathrm{Ba}$ & B & $\mathrm{C}$ & Дифолт & Укупно \\
\hline & Aaa & 930 & 30 & 15 & 10 & 8 & 4 & 2 & 1 & 1000 \\
\hline & $\mathrm{Aa}$ & 20 & 723 & 26 & 9 & 7 & 6 & 5 & 4 & 800 \\
\hline & A & 6 & 22 & 505 & 18 & 16 & 13 & 12 & 8 & 600 \\
\hline & Baa & 5 & 17 & 25 & 280 & 21 & 19 & 17 & 16 & 400 \\
\hline & $\mathrm{Ba}$ & 4 & 7 & 16 & 18 & 191 & 24 & 22 & 18 & 300 \\
\hline & B & 2 & 6 & 9 & 12 & 14 & 115 & 22 & 20 & 200 \\
\hline & $\mathrm{C}$ & 1 & 2 & 3 & 6 & 8 & 10 & 52 & 18 & 100 \\
\hline
\end{tabular}
у апсолутним вредностима

Миграциона матрица у апсолутним вредностима представља основ за израчунавање миграционих стопа и стопе неизвршења обавеза по свакој рејтинг-категорији. Стављањем у однос броја клијената који се на крају периода нађу у одређеној рејтинг-категорији са укупним бројем клијената који је на почетку периода био у одређе- 
ној рејтинг-категорији, добијамо све елементе миграционе матрице у релативним вредностима (Табела 2).

Табела 2. Једногодишња миграчиона матрища у релативним вредностима

\begin{tabular}{|c|c|c|c|c|c|c|c|c|c|}
\hline \multicolumn{10}{|c|}{ Рејтинг на крају године } \\
\hline \multirow{8}{*}{ 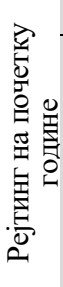 } & & Ааa & $\mathrm{Aa}$ & A & Baa & $\mathrm{Ba}$ & $\mathrm{B}$ & $\mathrm{C}$ & Дифолт Укупно \\
\hline & Aaа & $93,00 \%$ & $3,00 \%$ & $1,50 \%$ & $1,00 \%$ & $0,80 \%$ & $0,40 \%$ & $0,20 \%$ & $0,10 \% 100,00 \%$ \\
\hline & $\mathrm{Aa}$ & $2,50 \%$ & $90,38 \%$ & $3,25 \%$ & $1,13 \%$ & $0,88 \%$ & $0,75 \%$ & $0,63 \%$ & $0,50 \% \quad 100,00 \%$ \\
\hline & A & $1,00 \%$ & $3,67 \%$ & $84,17 \%$ & $3,00 \%$ & $2,67 \%$ & $2,17 \%$ & $2,00 \%$ & $1,33 \% 100,00 \%$ \\
\hline & $\mathrm{Baa}$ & $1,25 \%$ & $4,25 \%$ & $6,25 \%$ & $70,00 \%$ & $5,25 \%$ & $4,75 \%$ & $4,25 \%$ & $4,00 \% \quad 100,00 \%$ \\
\hline & $\mathrm{Ba}$ & $1,33 \%$ & $2,33 \%$ & $5,33 \%$ & $6,00 \%$ & $63,67 \%$ & $8,00 \%$ & $7,33 \%$ & $6,00 \% 100,00 \%$ \\
\hline & B & $1,00 \%$ & $3,00 \%$ & $4,50 \%$ & $6,00 \%$ & $7,00 \%$ & $57,50 \%$ & $11,00 \%$ & $10,00 \% 100,00 \%$ \\
\hline & $\mathrm{C}$ & $1,00 \%$ & $2,00 \%$ & $3,00 \%$ & $6,00 \%$ & $8,00 \%$ & $10,00 \%$ & $52,00 \%$ & $18,00 \% 100,00 \%$ \\
\hline
\end{tabular}

Можемо дефинисати математички исказ како се од стопа неизвршења обавеза по рејтинг-категоријама добија просечна стопа за цео портфолио:

$$
P D=\sum_{j=1}^{7} \frac{1}{w_{j}} \cdot P D_{j}=\sum_{j=1}^{7} \frac{1}{w_{j}} \cdot \frac{\sum_{i=1}^{t} m(D)_{i j}}{\sum_{i=1}^{t} m(N D)_{(i-1) j}}
$$

Смањењем учешћа клијената сврстаних у неку категорију $\left(w_{j}\right)$ може се утицати на висину просечне стопе неизвршења обавеза, што може бити интерни инструмент банке у управљању кредитним ризиком. Разврставање клијената у рејтинг-категорије, као хомогене групе са сличним карактеристикама ризичности, омогућује не само прецизнију оцену нивоа кредитног ризика клијената већ и идентификацију фактора који је детерминишу.

\section{КОРИШЋЕНИ ПОДАЦИ И МЕТОДОЛОГИЈА ИСТРАЖИВАҢА}

Емпиријско истраживање у овом раду састоји се из два дела. У првом делу рачунамо вероватноћу неизвршења обавеза банкарских дужника, док у другом делу рачунамо вероватноћу да банка уђе у статус дифолта. У оба случаја, примењујемо актуарски метод на емпиријске податке из банкарског сектора Републике Србије који потичу из временског периода од 30. 9. 2008. године до 31. 12. 2014. године. Избор периода анализе опредељен је настојањем да се уваже ефекти глобалне економске кризе на домаћи банкарски сектор, као и чињеницом да након 2014. године није било случајева дифолта банака. У циљу сагледавања фактора који опредељују ниво кредитног ризика, актуарски метод примењен је на одређене хомогене групе дужника, 
односно банака, формиране на основу њихових карактеристика ризичности.

Основни извор података за први део истраживања је преглед 100 највећих дужника појединачних банака, састављен према правилима извештајног система Народне банке Србије (НБС), на кварталном нивоу, као и подаци из биланса стања и биланса успеха за наведене дужнике. Анализом су обухваћени подаци о матичном броју и категорији класификације клијента према прописима НБС (Одлука о класификаиији билансне активе и ванбилансних ставки банке, чл. 20). Након елиминисања података који се односе на вишеструко приказивање истог клијента, финансијске институције и физичка лица, као и привредна друштва код којих су идентификовани проблеми са квалитетом података, или која се на почетку и крају посматраног периода нису налазила у портфолију 100 највећих дужника, добијена је варијабла којом се описује категорија класификације клијента са 1619 опсервација.

На основу те варијабле формирана је посебна варијабла бинарног типа која узима вредност 1 , ако је клијент банке на крају пословне године разврстан у категорију класификације Г и Д (као две најлошије категорије), и вредност 0 , у случајевима када је клијент на крају пословне године разврстан у категорију А, Б или В (што представља добру активу). Процена вероватноће да ова варијабла за одређену хомогену групу клијената има вредност 0 на почетку, а вредност 1 (дифолт клијента) на крају године коришћена је као показатељ кредитног ризика на нивоу клијента.

Специфичне карактеристике дужника које су обухваћене анализом односе се на квалитативна својства - величина привредног друштва и припадност сектору привредне делатности, као и две групе финансијских показатеља израчунатих на основу података из финансијских извештаја. У првој групи су показатељи који одражавају дејство фактора за које постоји интуитивна претпоставка о могућем утицају на ниво кредитног ризика (попут пада економске активности и прекомерне задужености), укључујући:

$$
\text { индекс прихода }=\frac{\text { приход од продаје текуће године }}{\text { приход од продаје претходне године }},
$$

рацио покривености дуга зарађивачком способношћу предузећа $(D S C R)=$ пословни добитак - амортизација

финансијски расходи $+\min \left(\frac{\text { (уугор. обавезе }+ \text { краткор. фин. обавезе }}{2}\right.$;краткор. фин. обавезе $)$

У другој групи финансијских показатеља су рацио бројеви који улазе у састав Алтмановог модела (Altman, 1968, pp. 594-596):

$$
\begin{aligned}
& X 1=\frac{\text { нето обртни капитал }}{\text { укупна актива }}, \\
& X 2=\frac{\text { нераспоређена добит }}{\text { укупна актива }},
\end{aligned}
$$




$$
\begin{aligned}
X 3 & =\frac{\text { профит пре исплате пореза и камата }(E B I T)}{\text { укупна актива }}, \\
X 4 & =\frac{\text { капитал }}{\text { обавезе }}, \\
X 5 & =\frac{\text { приходи од продаје }}{\text { укупна актива }} .
\end{aligned}
$$

На основу вредности разматраних карактеристика, формиране су хомогене групе дужника унутар узорка и за сваку од њих, применом актуарског метода, израчуната је вероватноћа неизвршења обавеза.

У другом делу истраживања посматрали смо кретање показатеља адекватности капитала пословних банака, као односа капитала и ризичне активе банке, у банкарском сектору Републике Србије у периоду од 30. 9. 2008. године до 31. 12. 2014. године. Вредност овог показатеља испод прописаног минимума указује на изложеност ризицима изнад могућности које дозвољава расположиви капитал банке. У посматраном периоду, управо кредитни ризик се издваја као кључни узрок неадекватности капитала појединих банака у банкарском сектору Републике Србије (Jović, 2017b). Отуда, пад вредности показатеља адекватности капитала испод $12 \%$, као регулаторног захтева (Одлука о адекватности капитала банке, чл. 3), можемо сматрати показатељем повећаног кредитног ризика.

Узорком су обухваћене све банке које су током посматраног периода имале лиценцу НБС, чиме је добијена 171 опсервација. Пратили смо да ли је код сваке у наредних годину дана дошло до пада показатеља адекватности капитала испод $12 \%$. Тиме је формирана варијабла бинарног типа која узима вредност 1 (у случају неадекватности капитала), односно 0, у супротном случају. Процена вероватноће да ова варијабла за одређену хомогену групу банака има вредност 0 на почетку, а вредност 1 (дифолт банке) на крају године коришћена је као показатељ кредитног ризика на нивоу банке.

У циљу израчунавања вероватноће уласка у статус дифолта по хомогеним групама банака, разматране су карактеристике банака које су потенцијалне детерминанте кредитног ризика, као што су: врста власништва, величина банке (према учешћу у укупној билансној суми банкарског система РС), учешће проблематичних кредита, степен концентрације потраживања (мерен учешћем првих 50 клијената у укупној кредитној активности банке), колатерализованост кредитног портфолија (као проценат покривености првих 20 клијената у портфолију банке адекватним инструментима обезбеђења), показатељ адекватности капитала, као и профитабилност банке, мерена стопом приноса на капитал (ROE), као односом нето добитка и капитала банке. Ниво кредитног ризика за сваку групу банака апроксимиран је процентуалним учешћем банака које су у периоду анализе забележиле пад показатеља адекватности капитала испод 12\% у укупном броју банака у датој групи. 


\section{РЕЗУЛТАТИ ИСТРАЖИВАҢА}

Од 1619 привредних друштава обухваћених узорком, 260 друштава нашло се у статусу дифолта током посматраног периода. На основу обрасца (2), следи да је просечна годишња стопа неизвршења обавеза дужника од последњег квартала 2008. до краја 2014. године на наведеном узорку привредних друштава износила $16,06 \%$. У Табели 3 приказане су вероватноће неизвршења обавеза по хомогеним групама дужника.

Добијени резултати показују да постоји разлика у нивоу кредитног ризика у зависности од величине привредног друштва. Полазећи од њиховог разврставања према локалним прописима (Закон о рачуноводству, 2013, чл. 6), микро и мала привредна друштва имају виши ниво кредитног ризика од средњих и великих друштава у посматраном узорку. Будући да је узорак формиран из прегледа највећих дужника банака, може се сматрати да су велика и средња друштва обухваћена репрезентативно. Међутим, добијене резултате не можемо сматрати адекватним приказом нивоа кредитног ризика у категорији микро и малих привредних друштава, већ само у једном њеном делу који се односи на високо задужена друштва. У највећем броју случајева, таква друштва су сателити већих друштава, почев од тога да су чланови појединих пословних групација, па до тога да су власнички и управљачки независна, али високо економски зависна од њих. Такође, не треба занемарити да је вероватноћа неизвршења обавеза заснована на броју случајева дифолта, а не на њиховој вредности.

Израчунате вероватноће неизвршења обавеза дужника показују да постоји разлика у нивоу кредитног ризика у зависности од припадности сектору привреде, при чему предњаче сектори попут административне и помоћне услужне делатности, пословања некретнинама, стручне, научне, иновационе и техничке делатности и уметности, забаве и рекреације. Ипак, треба имати у виду да су се друштва из одређених сектора, као што су грађевина, трговина и прерађивачка индустрија, задуживала више, због чега би рангирање сектора према нивоу кредитног ризика у вредносном исказу било другачије.

Стопе неизвршења обавеза даље упућују на то да је ниво кредитног ризика осетљив на пад прихода од продаје. Наиме, пад прихода од продаје до $20 \%$ у односу на претходни период доприноси томе да ова стопа буде већа за приближно $2 / 3$ у односу на привредна друштва са непромењеним или растућим приходом од продаје, док пад прихода за више од 20\% повећава ову стопу за нешто више од 6 пута. Изузетно, привредна друштва са индексом прихода изнад $150 \%$ имају стопу неизвршења обавеза приближно једнаку групи друштава која имају пад прихода од продаје до $20 \%$. Овакав резултат може се објаснити непоузданим финансијским извештајима, евидентирањем прихода који немају реални основ, као и могућим деловањем неког 
другог фактора кредитног ризика, као што су проблеми у наплати, ефекат девизног курса и сл.

Табела 3. Ниво кредитног ризика по хомогеним групама дужника

\begin{tabular}{|c|c|c|c|}
\hline $\begin{array}{l}\text { Карактеристика } \\
\text { дужника }\end{array}$ & \multicolumn{2}{|l|}{ Хомогена група } & $\begin{array}{c}\text { Вероватноћа } \\
\text { неизвршења } \\
\text { обавеза } \\
\end{array}$ \\
\hline \multirow{4}{*}{$\begin{array}{l}\text { Величина } \\
\text { привредног } \\
\text { друштва }\end{array}$} & \multicolumn{2}{|c|}{ Микро привредно друштво } & $41,0 \%$ \\
\hline & \multicolumn{2}{|c|}{ Мало привредно друштво } & $14,5 \%$ \\
\hline & \multicolumn{2}{|c|}{ Средње привредно друштво } & $10,0 \%$ \\
\hline & \multicolumn{2}{|c|}{ Велико привредно друштво } & $8,9 \%$ \\
\hline \multirow{5}{*}{$\begin{array}{l}\text { Сектор } \\
\text { привреде }\end{array}$} & \multicolumn{2}{|c|}{ Информисање и комуникације } & $7,8 \%$ \\
\hline & \multicolumn{2}{|c|}{$\begin{array}{l}\text { Трговина на велико и трговина на мало } \\
\text { Саобраћај и складиштење }\end{array}$} & $13,2 \%$ \\
\hline & \multicolumn{2}{|c|}{$\begin{array}{l}\text { Пољопривреда, шумарство и рибарство } \\
\text { Прерађивачка индустрија } \\
\text { Снадбевање водом; управљање отпадним водама, } \\
\text { контролисање процеса уклањања отпада и сл. }\end{array}$} & $15,3 \%$ \\
\hline & $\begin{array}{l}\text { Грађевинарство } \\
\text { Рударство } \\
\text { Услуге смештаја и исх } \\
\end{array}$ & & $19,0 \%$ \\
\hline & \multicolumn{2}{|c|}{$\begin{array}{l}\text { Административне и помоћне услужне делатности } \\
\text { Пословање некретнинама } \\
\text { Стручне, научне, иновационе и техничке делатности } \\
\text { Уметност, забава и рекреација }\end{array}$} & $31,3 \%$ \\
\hline $\begin{array}{l}\text { Индекс } \\
\text { прихода }\end{array}$ & Вредност показатеља & $\begin{array}{l}<80 \% \\
\geq 80 \% \text { и }<100 \% \\
\geq 100 \% \text { и }<150 \% \\
\geq 150 \%\end{array}$ & $\begin{array}{r}37,3 \% \\
10,2 \% \\
5,9 \% \\
9,5 \% \\
\end{array}$ \\
\hline DSCR & Вредност показатеља & $\begin{array}{l}<1 \\
\geq 1 \text { и }<2 \\
\geq 2\end{array}$ & $\begin{array}{r}19,2 \% \\
3,8 \% \\
2,4 \%\end{array}$ \\
\hline Показатељ X1 & Вредност показатеља & $\begin{array}{l}<0,25 \\
\geq 0,25 \text { и }<0,5 \\
\geq 0,5 \text { и }<0,75 \\
\geq 0,75\end{array}$ & $\begin{array}{l}18,4 \% \\
12,2 \% \\
10,1 \% \\
38,7 \%\end{array}$ \\
\hline Показатељ X2 & Вредност показатеља & $\begin{array}{l}<0,05 \\
\geq 0,05 \text { и }<0,1 \\
\geq 0,1 \text { и }<0,25 \\
\geq 0,25 \text { и }<0,5 \\
\geq 0,5 \text { и }<0,75 \\
\geq 0,75\end{array}$ & $\begin{array}{r}29,2 \% \\
17,1 \% \\
8,6 \% \\
5,9 \% \\
2,3 \% \\
0,0 \% \\
\end{array}$ \\
\hline Показатељ X3 & Вредност показатеља & $\begin{array}{l}<0 \\
\geq 0 \text { и }<0,025 \\
\geq 0,025 \text { и }<0,05 \\
\geq 0,05 \text { и }<0,1 \\
\geq 0,1\end{array}$ & $\begin{array}{r}56,5 \% \\
23,9 \% \\
19,6 \% \\
8,5 \% \\
4,6 \% \\
\end{array}$ \\
\hline Показатељ X4 & Вредност показатеља & $\begin{array}{l}<0,25 \\
\geq 0,25 \text { и }<0,5 \\
\geq 0,5 \text { и }<0,75 \\
\geq 0,75\end{array}$ & $\begin{array}{r}30,5 \% \\
13,2 \% \\
8,2 \% \\
5,4 \%\end{array}$ \\
\hline Показатељ X5 & Вредност показатеља & $\begin{array}{l}<0,25 \\
\geq 0,25 \text { и }<0,5 \\
\geq 0,5 \text { и }<0,75 \\
\geq 0,75 \text { и }<1 \\
\geq 1\end{array}$ & $\begin{array}{r}52,5 \% \\
28,3 \% \\
17,1 \% \\
7,1 \% \\
5,5 \% \\
\end{array}$ \\
\hline
\end{tabular}

Извор: Обрачун аутора, према подацима НБС. 
Рацио покривености дуга зарађивачком способношћу предузећа (DSCR) треба да покаже којој мери је изражена задуженост утицала на повећање броја привредних друштава са отежаном могућношћу отплате својих кредитних обавеза у посматраном периоду. Највећи проценат случајева неизвршења обавеза забележен је међу друштвима чија је зарађивачка способност била испод нивоа који је довољан за покриће просечних годишњих финансијских обавеза, и обрнуто. Услед погоршања пословног амбијента и пада њихове зарађивачке способности, привредна друштва која су на почетку кризе била високо задужена суочила су се са немогућношћу уредног сервисирања финансијских обавеза.

На основу Табеле 3 даље закључујемо да висок ниво кредитног ризика имају дужници са изражено ниским учешћем нето обртног капитала у укупној активи (испод 0,25$)$, а посебно дужници са изражено високим (изнад 0,75 ) учешћем нето обртног капитала у укупној активи. У првом случају, реч је о друштвима која имају низак ниво обртне имовине који је финансиран из дугорочних извора у односу на укупну имовину, што је очигледно представљало проблем у условима погоршања услова привређивања. Други случај може бити објашњен следећим разлозима: 1) високо учешће обртне имовине у укупној имовини привредног друштва у комбинацији са доминантим финансирањем обртне имовине из дугорочних извора финансирања, 2) дугорочна везаност обртних средстава у слабо утрживим залихама или слабо наплативим потраживањима, уколико релевантни показатељи указују на успоравање обрта залиха и потраживања.

Такође уочавамо да је ниво кредитног ризика утолико већи што су нераспоређена добит и зарађивачка способност привредног друштва мањи у односу на укупну активу. Са друге стране, привредна друштва са високим нивоом левериџа имају виши ниво кредитног ризика, и обрнуто. Коначно, на основу Табеле 3, увиђамо да мањој брзини обрта укупне активе одговара виши ниво кредитног ризика.

Од 171 опсервације која се односи на банке, код њих 17 забележен је пад вредности показатеља адекватности капитала испод $12 \%$ у току наредне године у оквиру посматраног периода. Применом обрасца (2) добијена је просечна годишња стопа неизвршења обавеза у периоду од последњег квартала 2008. до краја 2014. године на наведеном узорку банака од 9,94\%. У Табели 4 приказане су вероватноће поткапитализованости по хомогеним групама банака.

Добијени резултати показују да су стране банке код којих су идентификовани проблеми у пословању матице имале већу вероватноћу уласка у статус дифолта од државних банака. Ниво кредитног ризика виши је за групу малих банака (са појединачним учешћем у укупној билансној суми банкарског система испод $1,2 \%$ ) у поређењу са средњим и великим банкама (са појединачним учешћем између 
1,2 и $3,5 \%$, односно већим од $3,5 \%$, наведеним редоследом), за које је ниво кредитног ризика приближно исти. Гори квалитет кредитног портфолија, у смислу већег учешћа проблематичних кредита и већег степена концентрације потраживања, такође коинцидира са вишим нивоом кредитног ризика.

Табела 4. Ниво кредитног ризика по хомогеним групама банака

\begin{tabular}{|c|c|c|c|}
\hline $\begin{array}{l}\text { Карактеристика } \\
\text { банке }\end{array}$ & \multicolumn{2}{|l|}{ Хомогена група } & $\begin{array}{c}\text { Вероватноћа } \\
\text { поткапитали } \\
\text { зованости }\end{array}$ \\
\hline \multirow{4}{*}{$\begin{array}{l}\text { Врста } \\
\text { власништва }\end{array}$} & \multicolumn{2}{|c|}{$\begin{array}{l}\text { Банке у страном власништву код којих су } \\
\text { регистровани проблеми у пословању на нивоу } \\
\text { матичне групе }\end{array}$} & $20,0 \%$ \\
\hline & \multicolumn{2}{|c|}{ Банке у државном власништву } & $15,8 \%$ \\
\hline & \multicolumn{2}{|c|}{ Банке у домаћем приватном власништву } & $5,3 \%$ \\
\hline & \multicolumn{2}{|c|}{$\begin{array}{l}\text { Банке у страном власништву код којих нису } \\
\text { идентификовани значајни проблеми у } \\
\text { пословању на нивоу матичне групе }\end{array}$} & $2,7 \%$ \\
\hline Величина банке & \multicolumn{2}{|c|}{$\begin{array}{l}\text { Мале банке } \\
\text { Средње и велике банке }\end{array}$} & $\begin{array}{r}16,9 \% \\
5,0 \%\end{array}$ \\
\hline $\begin{array}{l}\text { Стопа } \\
\text { проблематичних } \\
\text { кредита }\end{array}$ & Вредност показатеља & $\begin{array}{l}<10 \% \\
\geq 10 \% \text { и }<20 \% \\
\geq 20 \% \text { и }<30 \% \\
\geq 30 \%\end{array}$ & $\begin{array}{r}2,7 \% \\
3,3 \% \\
14,0 \% \\
26,7 \%\end{array}$ \\
\hline $\begin{array}{l}\text { Степен } \\
\text { концентрације } \\
\text { потраживања }\end{array}$ & Вредност показатеља & $\begin{array}{l}<25 \% \\
\geq 25 \text { и < }<0 \% \\
\geq 50 \%\end{array}$ & $\begin{array}{r}0,0 \% \\
8,0 \% \\
18,0 \% \\
\end{array}$ \\
\hline $\begin{array}{l}\text { Степен } \\
\text { колатеризованос } \\
\text { ти портфолија }\end{array}$ & Вредност показатеља & $\begin{array}{l}<10 \% \\
\geq 10 \% \text { и }<20 \% \\
\geq 20 \% \text { и }<30 \% \\
\geq 30 \% \text { и }<40 \% \\
\geq 40 \% \text { и }<50 \% \\
\geq 50 \%\end{array}$ & $\begin{array}{r}3,3 \% \\
10,5 \% \\
23,1 \% \\
26,7 \% \\
16,7 \% \\
25,0 \%\end{array}$ \\
\hline $\begin{array}{l}\text { Показатељ } \\
\text { адекватности } \\
\text { капитала } \\
\end{array}$ & Вредност показатеља & $\begin{array}{l}\geq 12 \text { и }<14,5 \% \\
\geq 14,5 \% \text { и }<20 \% \\
\geq 20 \%\end{array}$ & $\begin{array}{r}46,1 \% \\
7,1 \% \\
0,0 \% \\
\end{array}$ \\
\hline ROE & Вредност показатеља & $\begin{array}{l}<0 \\
\geq 0\end{array}$ & $\begin{array}{r}21,0 \% \\
3,7 \%\end{array}$ \\
\hline
\end{tabular}

Изненађује резултат да је у групи банака са најнижим степеном колатерализованости портфолија (испод 10\%) забележен најмањи проценат случајева пада показатеља адекватности капитала испод $12 \%$, односно да банке са вишим степеном колатерализованости портфолија имају виши ниво кредитног ризика. Следствено, банке са ниском колатеризованошћу пласмана бирају добре клијенте, док банке чији је портфолио високо колатеризован покушавају да 
своје потенцијално проблематичне пласмане прикрију високим колатералима.

Груписањем банака према вредности показатеља адекватности капитала проверавамо на који начин су се, у контексту преузимања кредитног ризика, понашале банке са различитим нивоом капитала на почетку периода. Добијени резултати наговештавају да су се банке чији је показатељ адекватности капитала био близак прописаном минимуму током посматраног периода излагале оном нивоу кредитног ризика који није било могуће покрити расположивим капиталом. Коначно, код профитабилних банака (позитиван ROE) идентификован је мањи проценат случајева уласка у зону поткапитализованости у односу на банке које су пословале са губитком, што имплицира да профитабилност такође утиче на ниво кредитног ризика банке.

\section{ЗАКЉУЧАК}

У раду су образложене теоријско-методолошке основе актуарског метода процене вероватноће неизвршења обавеза дужника, који је прикладан за земље са недовољно развијеним тржиштем капитала. Применом тог метода на емпиријске податке о банкарском сектору Републике Србије, добијене су бројне индиције о ризичности појединих хомогених група дужника и банака. Како би се уважили ефекти погоршања макроекономских услова на домаћи банкарски сектор, анализом је обухваћен временски период од краја 2008. до краја 2014. године, тј. период након наступања глобалне економске кризе у којем су регистровани бројни случајеви дифолта дужника и неадекватности капитала банака. Резултати истраживања показују да је релативно виши ниво кредитног ризика испољен код привредних друштава која припадају сектору грађевинарства и послова са некретнинама. Такође, релативно висока вероватноћа неизвршења обавеза уочена је у случају привредних друштава са опадајућим индексом прихода од продаје, ниским нивоом покривености обавеза зарађивачком способношћу, неуобичајено ниским, али и високим односом нето обртног капитала и активе, високим левериџом и ниским коефицијентом обрта активе у посматраном периоду.

Стране банке код којих су идентификовани проблеми у пословању матице имале су већу вероватноћу неизвршења обавеза дужника од државних банака. Мање банке су склоније дифолту у односу на велике банке. Такође, банке чији се портфолио одликује већим учешћем проблематичних кредита и већом концентрацијом потраживања имају релативно виши ниво кредитног ризика, док су профитабилне и банке са већим нивоом капитала приликом уласка у кризу оствариле нижу стопу поткапитализованости. Коначно, изражена колатерализованост банкарског портфолија није умањила ниво изложе- 
ности кредитном ризику, зато што су се углавном иза добро колатерализованих пласмана појављивали дужници који имају неповољније пословне показатеље. Поред значајне економске интерпретације, добијени резултати могу бити коришћени као инпути за развој економетријских модела за процену нивоа и детерминанти кредитног ризика, као могућег будућег правца истраживања дате проблематике.

\section{ЛИТЕРАТУРА}

Almazari, A. A. (2014). Impact of internal factors on bank profitability: Comparative study between Saudi Arabia and Jordan. Journal of Applied Finance and Banking, 4(1), 125-140.

Altman, E. I. (1968). Financial Ratios, Discriminant Analysis and the Prediction of Corporate Bankruptcy. The Journal of Finance, 23(4), 589-609. doi: 10.2307/2978933

Altman, E., \& Sabato, G. (2007). Modeling Credit Risk for SMEs: Evidence from the US Market. Abacus, 43(3), 323-357.

Basel Committee on Banking Supervision. Credit Risk Modeling: Current Practices and Applications. (1999).

Bellotti, T., \& Crook, J. (2013). Forecasting and stress testing credit card default using dynamic models. International Journal of Forecasting, 29(4), 563-574, https://doi.org/10.1016/j.ijforecast.2013.04.003

Cantor, R., \& Hamilton, D. (2006). Measuring corporate default rates. Moody's Special Comment, November 2006, New York, NY: Moody's Investors Service.

Credit Suisse. CreditRisk+, A credit risk management framework. (1997).

Engelman, B., \& Rauhmeier, R. (2006). Basel II Risk Parameters: Estimation, Validation and Stress Testing, Berlin: Springer.

Hayden, E. (2002). Modeling an Accounting - Based Rating Sistem for Austrian Firms. (doktorska disertacija), Retrieved from: http://citeseerx.ist.psu.edu/viewdoc/ download?doi= 10.1.1.5.9852\&rep=rep1\&type $=$ pdf

Jorion, P. (2011). Financial Risk Manager Handbook. John Wiley \& Sons.

Јовић, Ж. (2017a). Анализа детерминанти кредитног ризика у условима изражене информачионе асиметрије: пример банкарског сектора Републике Србије [Analysis of credit risk determinants in terms of expressed information asymmetry: the case of the Republic of Serbia]. (докторска дисертација), Преузето ca: http://nardus.mpn.gov.rs/ handle/123456789/9421

Jović, Ž. (2017b). Determinants of Credit Risk - The Case of Serbia. Economic Annals, LXII(212), 155-188. DOI:10.2298/EKA1712155J

Nikolić, N., Žarkić-Joksimović, N., Stojanovski, Đ., \& Joksimović, I. (2013). The application of brute force logistic regression to corporate credit scoring models: Evidence from Serbian financial statements. Expert Systems with Applications, 40, 5932-5944. https://doi.org/10. 1016/j.eswa.2013.05.022

Nkusu, M. (2011). Nonperforming Loans and Macrofinancial Vulnerabilities in Advanced Economies. IMF Working Paper, WP/11/161, Washington, DC: International Monetary Fund.

Одлука о адекватности капитала банке [Decision on Capital Adequacy of Banks]. Службени гласник РС, бр. 46 (2011), 6 (2013) и 51 (2014).

Одлука о класификацији билансне активе и ванбилансних ставки банке [Decision on the Classification of Bank Balance Sheet assets and Off-Balance Sheet Items], Службени гласник РС, бр. 4 (2011), 57 (2012), 123 (2012), 43 (2013), 113 (2013), 135 (2014), 25 (2015), 38 (2015), 61 (2016), 69 (2016) и 91 (2016). 
Pesola, J. (2007). Financial fragility, macroeconomic shocks and banks' loan losses: evidence from Europe. Bank of Finland Research Discussion Papers, No. 15.

Podpiera, J., \& Weill, L. (2008). Bad Luck or Bad Management? Emerging Banking Market Experience. Journal of Financial Stability, 4, 135-148. https://doi.org/10. 1016/j.jfs.2008.01. 005

Закон о рачуноводству [Accounting Law], Службени гласник PC, бр. 62 (2013) и 30 (2018).

\title{
ESTIMATING PROBABILITY OF DEFAULT IN BANKING SECTOR - THE ACTUARIAL METHOD
}

\author{
Jelena Kočović1 Željko Jović $^{2}$, Marija Koprivica ${ }^{1}$ \\ ${ }^{1}$ University of Belgrade, Faculty of Economics, Belgrade, Serbia \\ ${ }^{2}$ National Bank of Serbia, Belgrade, Serbia
}

\begin{abstract}
Summary
The probability of default can be estimated using the actuarial method or the marketprice method. The actuarial method uses historical data from banks' portfolios on cases of the debtors' inability to meet their obligations and it is suitable for countries with insufficiently developed capital market and a bankocentric financial system. In order to assess the level of credit risk and to identify its possible determinants in the banking sector of the Republic of Serbia, by implementing the actuarial method, we calculated the probability of default of business entities as debtors, as well as of banks by certain homogeneous groups, formed on the basis of the observed risk characteristics. In an effort to appreciate the effects of the global economic crisis on the domestic banking sector, as well as due to the fact that there were no cases of bank default after 2014, the analysis covered the period from September 30, 2008 to December 31, 2014.

The probability that a client with good rating at the beginning of the year will have a bad rating at the end of the year was used for the purpose of measuring credit risk of bank debtors. On the basis of 1,619 observations, we estimated the average annual default rate of business entities as bank debtors in the amount of $16.06 \%$ in the observed period. The research results show that there are differences in the level of credit risk, depending on the size of the business entity and its business sector. Also, entities with a declining income index, low debt-service coverage ratio, unusually low but also unusually high net working capital to assets ratio, high leverage and low asset turnover ratio showed relatively higher probability of default in the observed period.

The level of credit risk of the bank is approximated by the probability that the capital adequacy ratio falls below the regulatory minimum of $12 \%$ during the business year. On the basis of 171 observations, we estimated the average annual default rate of banks in the amount of $9.94 \%$ in the observed period. Foreign banks in which the business operation problems are registered at the level of the parent company had a greater probability of their capital adequacy ratio dropping than state banks. Smaller banks are more prone to undercapitalization than large banks. Also, banks whose portfolio is characterized by higher share of problematic loans and higher concentration of receivables have a relatively higher level of credit risk, while profitable banks with greater capital on entering the crisis achieved a lower rate of default. Obtained results can be used for the purpose of selecting variables that will be included in econometric models for assessing the level of credit risk in the banking sector in Serbia.
\end{abstract}

